\author{
EWA BAGIŃSKA \\ https://doi.org/10.33995/wu2019.1.1
}

\title{
Podstawy odpowiedzialności cywilnej krajowych organów nadzoru finansowego w świetle doświadczeń zagranicznych
}

W artykule dokonano analizy podstaw prawnych roszczeń osób fizycznych i instytucji finansowych wobec władz publicznych o zapłatę odszkodowania pieniężnego za brak nadzoru nad rynkiem finansowym. Na podstawie badań orzecznictwa i ustawodawstwa zagranicznego podjęto próbę ustalenia wspólnych tendencji rozwojowych w krajach europejskich. Analiza koncentruje się wokół czynu niedozwolonego organów nadzoru finansowego oraz analizuje inne przesłanki roszczenia odszkodowawczego, które stanowiq ograniczenia odpowiedzialności. Na tym tle porównawczym przedstawiono teoretyczne podstawy odpowiedzialności Urzędu Komisji Nadzoru. W podsumowaniu zaprezentowano argumentacje za odpowiedzialnościq i przeciw odpowiedzialności organów nadzoru finansowego.

Słowa kluczowe: odpowiedzialność deliktowa organów nadzoru finansowego, naruszenie obowiązku nadzoru rynku finansowego i jego instytucji, odszkodowanie.

\section{Wprowadzenie}

Odpowiedzialność odszkodowawcza organów nadzoru finansowego jest kwestią budzạcą wiele sporów, które zwykle absorbują doktrynę w czasach kryzysu finansowego. ${ }^{1}$ Tymczasem zarówno regulacja rynku finansowego (tzn. ustanawianie przepisów i innych reguł o charakterze normatywnym), jak i nadzór nad nim (monitorowanie i egzekwowanie przepisów) moga prowadzić do wyrządzenia szkód majątkowych niezależnie od zewnętrznych okoliczności gospodarczych. Stałe rozszerzanie oraz pogłębianie obiektywizacji odpowiedzialności cywilnej w ogóle, a odpowiedzialności władzy publicznej w szczególności doprowadziły bowiem do takiego stanu świadomości i oczekiwań społeczeństwa, że pytaniem podstawowym nie jest „czy”, lecz „kto” ma płacić

1. Zob. E. Karner, Tort Law and the Financial Crisis: Basic Questions, ,Journal of European Tort Law” 2013, nr 4, s. 119. 
za powstały uszczerbek, a także ,jak szybko” i ,jaki jest zakres odszkodowania”. Poszkodowanym chodzi przede wszystkim o jak najpełniejsze wyrównanie doznanej szkody, zaś podstawy prawne tego wyrównania są drugorzędne. Coraz częściej więc inwestorzy (konsumenci) podnoszą roszczenia odszkodowawcze przeciwko organom nadzoru finansowego jako odrębnym podmiotom prawa lub przeciwko skarbowi państwa. ${ }^{2} \mathrm{~W}$ ostatnich dekadach niektóre sady europejskie zaczęły przychylać się do tych powództw, co spotkało się nie tylko z opozycją w doktrynie, lecz także z interwencją ustawodawców.

Źródło sporów teoretycznych bierze się m.in. z faktu, że obowiązki organów nadzoru są regulowane przez prawo publiczne, zaś roszczenia odszkodowawcze poszkodowanych są zakorzenione w prawie prywatnym. Wymaga to wypracowania dającej się uzasadnić oraz zaakceptować w świetle wartości konstytucyjnych równowagi między ochroną interesu publicznego (interesu ogółu społeczeństwa) a ochroną interesów indywidualnych. Ogólnie rzecz ujmując, cele nadzoru finansowego nie są zbieżne z interesami indywidualnymi, choć pośrednio mają im służyć. Normatywnie określonym celem nadzoru nad rynkiem finansowym jest zapewnienie prawidłowego funkcjonowania tego rynku, a więc jego stabilności, bezpieczeństwa oraz przejrzystości, zaufania do rynku finansowego, zapewnienie przestrzegania przez instytucje finansowe przepisów prawa, a także zapewnienie ochrony interesów wszystkich uczestników tego rynku, w tym m.in. konsumentów, inwestorów, ubezpieczających, ubezpieczonych i uprawnionych z umów ubezpieczenia. ${ }^{3}$

W razie niewłaściwego wykonywania obowiązków nadzoru możliwość odwołania się do środków ochrony prywatnoprawnej maja przede wszystkim nadzorowane instytucje finansowe (np. banki, ubezpieczyciele, giełdy), które mogą ucierpieć z powodu utraty reputacji lub dobrej pozycji finansowej na rynku, a ponadto akcjonariusze i udziałowcy podmiotów nadzorowanych. Zasadniczo środki nadzoru powinny odnosić skutek względem nadzorowanego podmiotu i nie powinny kształtować sytuacji prawnej klientów instytucji finansowej. ${ }^{4}$ Jednak moga one pośrednio wpływać na sytuację tych drugich, zwłaszcza gdy bezpośrednia ingerencja organu nadzoru w działalność podmiotu nadzorowanego wpłynie na zdolność bieżącego zarządzania tym podmiotem (np. zawieszenie członków zarządu), spowoduje zablokowanie środków na rachunku czy uruchomienie procedury upadłości lub likwidacji danego podmiotu itd. Dlatego też ochrona cywilnoprawna przysługuje także osobom trzecim (np. deponentom, inwestorom indywidualnym, ubezpieczonym) w zakresie, w jakim ochrona publicznoprawna ich roszczeń nie wyrówna poniesionej szkody. ${ }^{5}$

2. Zob. R.J. Dijkstra, Liability of Financial Supervisory Authorities in the European Union, „Journal of European Tort Law" 2012, nr 3, s. 346.

3. Por. art. 2 ustawy o nadzorze nad rynkiem finansowym z dnia 21 lipca 2006 r. (tj. z dnia 17 stycznia 2019 r., Dz. U. 2019, poz. 298) oraz rozporządzenie Parlamentu Europejskiego i Rady (UE) nr 575/2013 z dnia 26 czerwca 2013 r. w sprawie wymogów ostrożnościowych dla instytucji kredytowych i firm inwestycyjnych, zmieniającego rozporzadzenie (UE) nr 648/2012 (Dz. Urz. UE L 176 z 27.06.2013, s. 1, z późn. zm.), oraz art. 329 ust. 2 ustawy o działalności ubezpieczeniowej i reasekuracyjnej z dnia 11 września 2015 r., tj. z dnia 9 maja 2018 r. (Dz. U. 2018, poz. 999).

4. Wodniesieniu do nadzoru bankowego zob. M. Bączyk, Zarys prawa bankowego. Część l. Prawo systemu bankowego, TNOiK, Toruń 2000, s. 154-155.

5. Np. obowiązkowy system gwarantowania depozytów wprowadzonych w krajach UE na podstawie dyrektywy Parlamentu Europejskiego i Rady 2014/49/UE z dnia 16 kwietnia 2014 r. w sprawie systemów gwarancji depozytów (Dz. Urz. UE L 173 z 12.06.2014, s. 149) obejmuje roszczenie osób fizycznych, prawnych, niepełnych osób prawnych, szkolnych kas oszczędnościowych, pracowniczych kas zapomogowo-pożyczkowych oraz rad rodziców (a w przypadku spółdzielczej kasy oszczędnościowo-kredytowej również innych podmiotów) o świadczenie pieniężne - do wysokości 100 tys. euro. 
Z uwagi na to, że roszczenie o odszkodowanie jest zawsze roszczeniem cywilnoprawnym, jego podstawowe elementy są wspólne dla większości systemów prawnych: zdarzenie powodujące powstanie odpowiedzialności, szkoda i związek przyczynowy. Konieczność wykazania związku przyczynowego między szkodą a działaniem lub zaniechaniem konkretnego podmiotu (lub kilku podmiotów] może okazać się istotna przeszkodą dla dochodzenia roszczenia. Ponadto, dodatkowe warunki odpowiedzialności moga wynikać z uszczegółowienia przepisów bądź z immanentnych cech danego systemu odpowiedzialności cywilnej. Jeśli dodamy do tego fakt, że poszkodowani przedsiębiorcy moga przenosić straty finansowe na swoich udziałowców, to dyskusja obejmuje także problem kompensacji szkód osób pośrednio poszkodowanych (problem kompensacji tzw. szkody czysto ekonomicznej - pure economic loss].

Poniższa analiza koncentruje się na pierwszej przesłance odpowiedzialności z tytułu niewłaściwego nadzoru lub jego braku, tj. zdarzenia będącego źródłem odpowiedzialności. Wobec nikłych doświadczeń polskich należy odwołać się do praktyki zagranicznej. Najnowsze badania porównawcze wykazały, że w krajach Unii Europejskiej brak wspólnego podejścia do kwestii odpowiedzialności z tytułu nadzoru finansowego. ${ }^{6}$ Niemniej jednak powinniśmy spróbować zidentyfikować pewne zbieżne tendencje rozwojowe, co może pomóc w rozpoczęciu szerszej dyskusji nad kształtem odpowiedzialności organów sprawujących nadzór finansowy nad rynkiem ubezpieczeniowym, kapitałowym i bankowym w Polsce.

W artykule zostały pominięte kwestie publicznoprawne, należące do wykładu prawa rynku finansowego (zwłaszcza cele nadzoru, rodzaje, funkcje nadzoru, środki nadzorcze itd.). Moga one jednak mieć istotne znaczenie dla kwestii odpowiedzialności. Jak wiadomo, organizacja systemów nadzoru nad rynkami finansowymi nie jest w Europie jednolita, podobnie jak różny jest charakter prawny podmiotów sprawujaccych nadzór i ich powiązanie z budżetem państwa. Moga one być organami administracji państwowej o różnym stopniu zależności od rządu, organami państwowo - samorządowymi, w których skład wchodza przedstawiciele maklerów i inwestorów, bądź organami samorządu uczestników obrotu rynku finansowego.? Ponadto należy mieć na uwadze, że organy krajowe mają obowiązek współpracować z organami nadzoru UE (m.in. z Komisją Europejską oraz trzema Europejskimi Urzędami Nadzoru - Europejskim Urzędem Nadzoru Bankowego (EUNB), Europejskim Urzędem Nadzoru Giełd i Papierów Wartościowych (ESMA) oraz Europejskim Urzędem Nadzoru Ubezpieczeń i Pracowniczych Programów Emerytalnych (EIOPA), a także Europejskim Bankiem Centralnym]. Te okoliczności o charakterze ustrojowym mają bezpośredni wpływ na legitymacje bierną w procesie odszkodowawczym. Podmiotem odpowiedzialnym z tytułu wyrządzenia szkody z reguły będzie sama instytucja nadzorcza (publiczny organ

6. Zob. R.J. Dijkstra, Is limiting financial supervisory liability a way to prevent defensive conduct? The outcome of a European survey, „European Journal of Law and Economics” 2017, nr 43, https://doi.org/10.1007/ s10657-015-9484-1 [dostęp: 15.05.2019], idem, Liability ... ; D. Nolan, The Liability of Financial Supervisory Authorities, „Journal of European Tort Law” 2013, nr 4.

7. Zob. A. Michór, Komisja nadzoru finansowego jako gwarant stabilności systemu finansowego w Polsce, „Prawo Mediów Elektronicznych" 2010, nr 1, s. 31. Dominuje niezależność budżetu organu nadzoru od budżetu państwa, co jest również rekomendowane przez Program Oceny Sektora Finansowego (Financial Sector Assessment Programme - FSAP) dokonywany przez Międzynarodowy Fundusz Walutowy i Bank Światowy. https://www.imf.org/external/np/fsap/fssa.aspx [dostęp: 10.05.2019]. W odniesieniu do Polski zob. raport Republic of Poland: Financial System Stability Assessment, https://www.imf.org/en/Publications/CR/Issues/2016/12/31/Republic-of-Poland-Financial-System-Stability-Assessment-40809 [dostęp: 10.05.2019]. 
nadzoru, który posiada osobowość prawna, a więc i majątek], bądź państwo, które stoi za instytucją (czyli w rezultacie legitymowany biernie będzie skarb państwa). Niewykluczone wreszcie, że ciężar odpowiedzialności, który co do zasady spoczywa na instytucji, będzie mógł być częściowo przesunięty na pracownika (funkcjonariusza) państwowego organu nadzoru finansowego, co będzie miało w szczególności miejsce w przypadku, gdy dopuścił się on rażącego niedbalstwa lub działał z zamiarem wyrządzenia szkody. Fakt wypłacalności publicznego organu nadzoru istotnie zmniejsza rolę ewentualnej odpowiedzialności bezpośredniej funkcjonariusza, chociaż nie można wykluczyć, że organ nadzoru wystapi z roszczeniem regresowym z tytułu wypłaconych odszkodowań. ${ }^{8} \mathrm{~W}$ związku z powyższym roszczenia odszkodowawcze kierowane przeciwko podmiotom wykonującym nadzór finansowy w wybranych krajach europejskich mogą opierać się na różnych przesłankach materialnoprawnych.

\section{Ewolucja przesłanek odpowiedzialności organów nadzoru finansowego w świetle tendencji europejskich}

Odpowiedzialność cywilna organów nadzoru osadzona jest w reżimie deliktowym, ponieważ nie możemy mówić o nawiązaniu stosunku umownego pomiędzy organem nadzoru jako podmiotem władzy publicznej a osobą fizyczną lub prawną. ${ }^{9} \mathrm{~W}$ zagranicznych porzadkach prawnych odpowiedzialność władz publicznych może podlegać ogólnym przepisom deliktowym (znajdującym się w kodeksach cywilnych), szczególnym przepisom deliktowym bądź przepisom należącym do domeny prawa publicznego. W większości krajów europejskich odpowiedzialność władz publicznych jest obecnie regulowana przez specjalne reguły, które są bardziej rygorystyczne niż ogóIne reguły dotyczacce odpowiedzialności za czyn niedozwolony. Jedynie w systemach common law zachowano zasadniczo jednolite zasady odpowiedzialności osób publicznych i prywatnych. ${ }^{10}$

Współczesny model odpowiedzialności władz publicznych w większości państw europejskich opiera się na zobiektywizowanej winie lub czysto obiektywnej przesłance bezprawności (niezgodności z prawem) działania lub zaniechania podmiotów władzy. Obiektywizacja odpowiedzialności ma ugruntowanie w wartościach i zasadach konstytucyjnych. Mimo że wina sensu stricto (element subiektywny) utraciła pierwszorzędne znaczenie praktyczne w większości krajów, to jednak wspomniana obiektywizacja z trudem toruje sobie drogę, gdy chodzi o działania egzekutywy oparte na swobodzie uznania. Z badań porównawczych wynika, że w odniesieniu do specyficznych rodzajów aktywności państwowej w wielu krajach utrzymuje się nadal przesłanka winy w stopniu wyższym niż zwykłe niedbalstwo. Dotyczy to zwłaszcza regulacji i nadzoru nad działalnością bankową oraz nad innymi sektorami rynku finansowego. ${ }^{11}$

8. Zob. K. Oliphant, The liability of public authorities in comparative perspective, [w:] The Liability of Public Authorities in Comparative Perspective, [ed.] K. Oliphant, Intersentia, Cambridge-Antwerp-Portland 2016, s. 868.

9. Zob. szerzej E. Bagińska, Liability in Tort of Financial Supervisory Authorities - a comparative analysis, „Studia luridica Toruniensia" 2018 [w druku].

10. Zob. E. Bagińska, Odpowiedzialność odszkodowawcza za wykonywanie władzy publicznej, CH Beck, Warszawa 2006, s. 125, K. Oliphant, The liability..., s. 881.

11. Zob. E. Bagińska, Odpowiedzialność..., s. 131. 
Z analizy najnowszego orzecznictwa i ustawodawstwa wyłania się dość niejednolity obraz. Źródłem roszczeń odszkodowawczych z tytułu wykonywania nadzoru finansowego jest bezprawność (Czechy, Polska, Grecja, Hiszpania), „zwykłe” niedbalstwo w nadzorze (Dania, Szwecja, Węgry), rażące niedbalstwo (Francja, Belgia, Włochy) lub umyślność (Wielka Brytania, Irlandia, Holandia, Bułgaria, Malta, Estonia]. ${ }^{12}$ Co więcej, w niektórych krajach odpowiedzialność została wyłączona w wyniku określonych zabiegów ustawodawcy (Niemcy, częściowo w Austrii).

Można wskazać wiele przyczyn zawężania odpowiedzialności w omawianej dziedzinie.

Z punktu widzenia celu i zadań nadzoru finansowego, także w świetle integracji systemu nadzoru nad rynkiem finansowym w UE, decyzje i inne czynności krajowych organów nadzorczych muszą uwzględniać wiele wartości i interesów niekoniecznie ze sobą zbieżnych (istnieje np. zasadniczy konflikt między obowiązkiem wobec społeczeństwa, jak np. obowiązek ochrony stabilności systemu bankowego, a obowiązkiem ochrony interesów prywatnych). Wyrażana jest też obawa, że „zagrożenie” odpowiedzialnością cywilną może mieć negatywny wpływ na skuteczne wykonywanie funkcji nadzorczych (tzw. chilling effect ${ }^{13}$ ).

Powiązany z powyższym jest argument, że uprawnienia regulacyjne i nadzorcze nie powinny podlegać kontroli sądów powszechnych, bowiem doszłoby do powtórnej oceny politycznych, społecznych lub ekonomicznych podstaw aktu stanowiącego pierwotną kompetencję władzy wykonawczej. Nawet gdyby akt nadzoru był zawiniony, to odpowiedzialność powinna być wyłączona ze względów pragmatycznych, gdyż interes publiczny przeważa tutaj nad interesem prywatnym.

W doktrynie podnoszonych jest ponadto kilka argumentów z zakresu polityki prawa, takich jak potrzeba racjonalnego wydawania publicznych środków finansowych czy też konieczność zapewnienia marginesu swobody w zakresie uprawnień dyscyplinarnych (quasi-sądowych) organów nadzoru. ${ }^{14}$ Władze publiczne nie powinny być zniechęcane do korzystania ze swoich uprawnień w celu ochrony interesu ogólnego, społecznego, nawet kosztem interesu indywidualnego.

W odniesieniu do tych argumentów należy podnieść, że wpływ odpowiedzialności podmiotów nadzorujących na efektywność nadzoru jest trudny do przewidzenia, a ponadto brak jakichkolwiek danych empirycznych potwierdzających tezę, że odpowiedzialność deliktowa ma odstraszający (deterrent) wpływ na zachowanie organów władzy publicznej. ${ }^{15}$ Istotniejszy jest argument, że skoro danym podmiotom przyznano uprawnienia w celu realizacji określonych zadań publicznych, to ponoszą one odpowiedzialność za właściwe korzystanie z tych uprawnień.

Rzecz jasna, organy władzy nie mogą korzystać ze swobody uznania w sposób arbitralny lub nieograniczony, co wynika z zasady legalizmu. Uprawnienia dyskrecjonalne organów nadzoru finansowego wymagają zatem reakcji prawnej wówczas, gdy mamy do czynienia z arbitralnościa (nieproporcjonalnością) działania lub niewykonywaniem funkcji i uprawnień. Zwykłe zaniedbanie, polegające na niedopełnieniu obowiązków bądź niewłaściwym zarządzaniu, nie wystarczy, aby pociagnąć państwo lub sam podmiot nadzoru do odpowiedzialności odszkodowawczej.

Ogólnie rzecz biorąc, uczestnicy rynku finansowego są bardziej narażeni na szkodę, jeżeli władze ingeruja w ich działalność gospodarczą lub reagują nadmiernie na pewne fakty. W praktyce jednak najczęstsze uchybienia organów nadzorczych polegają na zaniechaniu podjęcia działań

12. Zob. R.J. Dijkstra, Liability ..., s. 370 .

13. Zob. D. Nolan, op. cit., s. 221.

14. Ibidem, 211.

15. Zob. R.J. Dijkstra, Is limiting ..., s. 61, 74 . 
i środków wykonawczych w stosunku do podmiotów rynku, a z roszczeniem odszkodowawczym występują osoby trzecie. Przy zaniechaniu podjęcia środków nadzorczych inaczej postrzega się przesłankę bezprawności i winy, a ponadto związek przyczynowy między aktem naruszającym sferę prawną podmiotu nadzorowanego jest zazwyczaj łatwiejszy do ustalenia niż związek przyczynowy między brakiem ingerencji nadzorczej a naruszeniem interesów majątkowych osób trzecich.

Jak wskazano wyżej, w większości krajów europejskich działania mieszczące się w granicach uznania nie pociagną za sobą odpowiedzialności za szkodę, gdyż powód musi udowodnić rażące niedbalstwo (culpa lata) lub złą wiarę pozwanego podmiotu. Rażące niedbalstwo określa sytuację, w której organ nadzoru przy zachowaniu zwyczajnej staranności powinien był ujawnić nadużycie finansowe lub inne nieprawidłowości w danej instytucji ${ }^{16}$, lub powinien był ustalić fakt wystapienia trudności finansowych, bądź powinien był działać bardziej zdecydowanie (np. cofnąć zezwolenie na prowadzenie działalności lub nałożyć inne sankcje). Z kolei przez działanie w „złej wierze", które to pojęcie jest charakterystyczne dla systemów common law, można uznać sytuację bliską celowemu wyrządzeniu szkody. ${ }^{17}$

Problem marginesu uznania w zakresie podejmowania czynności nadzoru ilustruje hiszpańska sprawa dotycząca niewywiązywania się z obowiązków ustawowych przez Krajową Komisję Rynku Papierów Wartościowych (CNMV), co rzekomo miało doprowadzić do upadłości agencji inwestycyjnych. W Hiszpanii uznaje się, że prawodawstwo nie przyznaje CNMV bezwzględnych uprawnień w zakresie natychmiastowej kontroli i interwencji, a nawet zawieszenia działalności firm inwestycyjnych w przypadku pojawienia się informacji lub oznak występowania nieprawidłowości. Hiszpański Sąd Najwyższy orzekł, że CNMV dysponuje swobodą uznania wymaganą do oceny okoliczności sprawy zgodnie z doświadczeniem i wiedzą fachową. Rozsądne wykonywanie uprawnień z zakresu nadzoru finansowego musi uwzględniać ewentualny wpływ planowanych działań na rynek akcji, na którym działa określona spółka. Podejmowanie drastycznych środków bez przeprowadzenia niezbędnych kontroli lub bez umożliwienia zarządowi złożenia wyjaśnień i, w razie potrzeby, skorygowania procedur nie może być uznane za rozsądne. ${ }^{18}$

Z kolei w holenderskiej sprawie Vie d'Or (2006) ${ }^{19}$ dotyczącej roszczeń osób ubezpieczonych w towarzystwie ubezpieczeń na życie, które ogłosiło upadłość, sąd uznał, że kluczową kwestia jest to, czy organ nadzoru w konkretnych okolicznościach istniejących w chwili wydania decyzji i na podstawie informacji dostępnych w tym momencie mógł w sposób racjonalny podjąć decyzję taką, jaką podjałł. Pozwany organ miał, zdaniem sądu, obowiązek podjęcia skutecznych środków, a w przypadku ich niepowodzenia powinien był wdrożyć inne środki. Jednakże, ponieważ organowi temu przyznano duży margines uznania przy podejmowaniu decyzji i ingerowaniu w działalność zakładów ubezpieczeń, uprawnienia sądów w zakresie weryfikowania tych decyzji powinny być ograniczone. Powyższa reguła została potwierdzona przez Sąd Najwyższy Holandii w sprawie

16. Zob. Orz. Three Rivers District Council v. Bank of England III [2000] 2 WLR 1220.

17. Zob. D. Nolan, op. cit., s. 190-191.

18. Wyrok STS z dnia 16 maja 208, RJ 2008/2756; zob. M. Martin-Casals, J. Ribot, The liability of public authorities in Spain, [w:] The Liability of Public Authorities in Comparative Perspective, [ed.] K. Oliphant, Intersentia, Cambridge-Antwerp-Portland 2016, s. 488-489.

19. Wyrok z dnia 13 października 2006 r., NJ 2008, 527, zob. M.G. Faure, T. Hartlief, The Netherlands, [w:] European Tort Law 2007, [ed.] E. Karner, B.C. Steininger, Springer, Wien-New York 2008, s. 416. 
Autoriteit Financiële Markten (2014) dotyczącej postępowania organów nadzoru bankowego. ${ }^{20}$ Jednak decyzją ustawodawcy od dnia 1 lipca 2012 roku Autoriteit Financiële Markten i Holenderski Bank Centralny odpowiadają cywilnie wyłącznie za działania umyślne. ${ }^{21}$

W krajach, w których odpowiedzialność władz publicznych opiera się na ogólnych zasadach odpowiedzialności zawartych w kodeksach cywilnych [tak jak we wspomnianym prawie holenderskim], obserwuje się próby poszerzenia ochrony sądowej uczestników rynku finansowego. Tytułem przykładu, w 2001 roku włoski Sąd Kasacyjny dopuścił odpowiedzialność cywilna włoskiego Urzędu Nadzoru Finansowego - Commissione Nazionale per la Societa e la Borsa (CONSOB) ${ }^{22}$ za brak nadzoru nad rynkiem kapitałowym. Zdaniem sądu CONSOB miała obowiązek przeprowadzenia zarówno prewencyjnej, jak i późniejszej weryfikacji prospektu emisyjnego spółki (który zawierał nieprawdziwe informacje i oświadczenia), obowiązek ostatecznego wstrzymania transakcji oraz przeprowadzenia w razie potrzeby kontroli na nadzorowanym rynku. Zaniedbanie tych obowiązków upoważnia skarżących do powołania się na ogólną klauzulę odpowiedzialności za winę (art. 2043 włoskiego k.c.). W wyroku z dnia 23 marca 2011 roku 23 Sąd Kasacyjny potwierdził, że CONSOB nie tylko jest organem nadzoru, ale także ma równorzędny obowiązek ochrony inwestycji prywatnych i krajowych. W konsekwencji CONSOB ponosi odpowiedzialność za rażące niedbalstwo w wykonaniu obowiązku ochrony oszczędności prywatnych i krajowych, co gwarantuje również konstytucja. W odpowiedzi na pierwsze orzeczenie ustawodawca włoski ograniczył w 2006 roku odpowiedzialność CONSOB do przypadków rażącego niedbalstwa lub umyślności. ${ }^{24}$

Ustawowe wyłączenie lub istotne ograniczenie odpowiedzialności organów nadzoru w kilku krajach (mające pewien związek z zalewem powództw po kryzysie finansowym z 2007 roku ${ }^{25}$ ) doprowadziło do efektu domina w Europie, zwłaszcza tam, gdzie duże instytucje finansowe prowadzące działalność na skalę międzynarodową podlegały ogólnym zasadom (nieograniczonej) odpowiedzialności za czyny niedozwolone. Ta tendencja regulacyjna widoczna jest także w państwach niebędących ośrodkami międzynarodowej działalności finansowej (m.in. Litwa ${ }^{26}$ i Chorwacja). Należy dodać, że idea limitowania odpowiedzialności wynika z zasady nr 2 Podstawowych Zasad Efektywnego Nadzoru Bankowego Bazylejskiego Komitetu Nadzoru Bankowego (2012 27]. Zasada ta zaleca pełną ochronę prawną (immunitet) organów nadzoru i ich pracowników w stosunku do działań podejmowanych w dobrej wierze, ogranicza się jednak tylko do nadzoru bankowego (niemniej, jest to największy rynek podlegający nadzorowi).

20. Wyrok z dnia 21 listopada 2014 r., X v Autoriteit Financiële Markten, RvdW 2014, 1310, zob. J.M. Emaus, A.L.M. Keirse, [w:] European Tort Law 2014, [ed.] E. Karner, B.C. Steininger, Springer, Berlin-New York 2015, s. 429.

21. Wet aansprakelijkheidsbeperking DNB en AFM, zob. J.M. Emaus, A.L.M. Keirse, The Netherlands, [w:] European Tort Law 2012, [ed.] K. Oliphant, B.C. Steininger, Springer, Berlin-New York 2013, s. 469, 470.

22. Wyrok z dnia 3 marca 2001 r., nr 3132, zob. E. Navarretta, E. Bargelli, Italy, [w:] European Tort Law 2001, [ed.] H. Koziol, B.C. Steininger, Springer, Wien-New York 2002 s. 34 ?

23. Wyrok z dnia 23 marca 2011 r., nr 6681, zob. E. Bargelli, Italy, [w:] European Tort Law 2011, [ed.] K. Oliphant, B.C. Steininger, Springer, Berlin-New York 2012, s. 339, 346.

24. Art 24(6) of the Law 28 of December 2005, zmieniony przez Law of 29 December 2006, no 303, art 4, subsec 3, lit d.

25. Zob. E. Karner, Tort Law..., s. 119-120.

26. Zob. S. Selelionyte-Drukteiniene, L. Saltinyte, Lithuania, [w:] European Tort Law 2015, [ed.] E. Karner, B.C. Steininger, Springer, Berlin-New York 2016, s. 349; S. Baretić, Croatia, [w:] European Tort Law 2013, [ed.] K. Oliphant, B.C. Steininger, Springer, Berlin-New York 2014, s. 110-111.

27. Zob. www.bis.org [dostęp: 15.05.2019]. 
Na powyższym tle jako skrajne przedstawia się stanowisko systemów germańskich, w szczególności niemieckiego, szwajcarskiego i austriackiego. Brak odpowiedzialności organów nadzoru wobec osób trzecich (deponentów, inwestorów) wynika częściowo z teoretycznych ograniczeń systemu prawa odpowiedzialności cywilnej w tych krajach, a częściowo z interwencji ustawodawcy. W germańskiej tradycji prawnej i porządkach prawnych pozostających pod jej wpływem (Dania, Holandia, Włochy) odpowiedzialność organów władzy publicznej jest ograniczona przez tzw. doktrynę ochronnego celu przepisów prawnych (Schutznormtheorie). Oznacza ona, że państwo odpowiada za szkodę jedynie wówczas, gdy funkcjonariusz, naruszając obowiązek służbowy, naruszył jednocześnie normę prawną chroniąca prawo podmiotowe poszkodowanego, tj. normę mającą na celu ochronę interesu jednostki bądź grupy jednostek, do której należy poszkodowany. Cel ochronny nie zawsze wynika wprost z ustawy, stąd w praktyce spełnienie tej przesłanki często zależy od oceny sądu, kierującego się różnymi kryteriami zaproponowanymi w nauce i judykaturze. ${ }^{28} \mathrm{~W}$ dużym uproszczeniu, co do zasady państwo ma odpowiadać zawsze, chyba że określony obowiązek publicznoprawny miał charakter ogólny. Jednak dla powstania odpowiedzialności z tytułu zaniechania, brak podjęcia czynności musi urastać do nadużycia swobody uznania lub nieuzasadnionej arbitralności funkcjonariuszy. ${ }^{29}$ Obowiązek ochronny w stosunku do jednostki można przyjąć z uwagi na charakter działania organów publicznych (np. wskazujący na obowiązek udzielenia odpowiedniej informacji lub ostrzeżenia), sposób działania powodujący zagrożenie dla zdrowia i życia, na skutki działania oraz gdy obowiazkowi publicznoprawnemu odpowiada prawo jednostki do żądania jego realizacji.Przy ocenie celu ochronnego przepisów istotną rolę pełnią względy polityki prawa. Zdarza się nawet, że decyzje sądów nie spotykają się z aprobatą ustawodawcy. Tak też stało się, gdy niemiecki Federalny Sąd Najwyższy (BGH) orzekł, że ustawa regulująca nadzór bankowy kreuje obowiązki organu nadzoru bankowego wobec klientów banku. ${ }^{30}$ BGH uznał, że takie zdarzenia, jak nielegalne transakcje bankowe bądź upadłość banku mogạ być przyczynowo powiązane ze sprawowaniem niewłaściwego nadzoru przez organ federalny. W opinii sądu funkcje tego organu mają charakter zbliżony do funkcji policji. W związku z tym, że w świetle konstytucji RFN obowiązkiem policji jest chronić społeczeństwo i poszczególnych obywateli, również prawa majątkowe klientów banku znajduja się w zasięgu celu ochronnego ustawy o nadzorze bankowym, a nie tylko stanowią refleks tych praw, jak przyjmowano we wcześniejszym orzecznictwie. Niepodjęcie dostatecznych środków nadzoru przez organ nadzoru bankowego świadczy o winie w postaci niedbalstwa. Bezpośrednią konsekwencją tego orzeczenia była nowelizacja prawa bankowego oraz prawa ubezpieczeniowego z 1985 roku, która wprowadziła wyraźny przepis, że niemiecki organ nadzoru finansowego (Bundesanstalt für Finanzdienstleistungsaufsicht - BaFin], jest niezależnym podmiotem prawa publicznego, który sprawuje nadzór finansowy wyłącznie w interesie publicznym. ${ }^{31}$

Powyższa interwencja ustawodawcy wywołała wątpliwości co do jej zgodności z art. 34 Konstytucji RFN, gwarantującym prawa obywateli do odszkodowania za wykonywanie władzy publicznej. ${ }^{32}$ Ten argument konstytucyjny został jednak obalony przez BGH w orzeczeniu z dnia

28. Zob. H.J. Papier, [w:] Münchener Kommentar, Schuldrecht, Besonderer Teil, CH Beck, München 1997, s. 1936-1955.

29. Zob. E. Bagińska, Odpowiedzialność ..., s. 65-66.

30. Wyrok BGH z dnia 15 lutego 1979 r., NJW 1979, s. 1354.

31. Art 4 para. 4 Finanzdienstleistungsaufsichtsgesetz vom 22. April 2002 (BGBI. I S. 1310).

32. Zob. H.J. Papier, op. cit., s. 1946. 
20 stycznia 2005 roku, w którym sąd orzekł, że poprzednio obowiązujące wyłączenie odpowiedzialności organu nadzorczego wobec deponentów za winę w nadzorze nad instytucją finansową nie naruszało art. 34 ani art. 14 ust. 1 (dotyczącego ochrony własności) konstytucji RFN. ${ }^{33}$ Publiczne organy regulacyjne i nadzorcze maja bowiem szeroki margines uznania w realizacji obowiązków ochronnych, zaś pozytywny obowiązek ochrony spoczywa wyłącznie na parlamencie.

Dla porównania: Szwajcarski Trybunał Federalny w 2012 roku oddalił powództwo akcjonariusza banku (kantonu genewskiego) przeciwko Konfederacji Szwajcarskiej za wadliwy nadzór bankowy. ${ }^{34} \mathrm{~W} 2000$ roku kanton genewski musiał dokapitalizować swój bank (Cantonal Bank of Geneva) na kwotę 3,4 mld CHF w celu zapobieżenia upadłości. Następnie zażądał zwrotu tej kwoty od rządu federalnego, twierdząc, że organ nadzoru bankowego (wówczas Federalna Komisja Bankowa) nie dochował należytej staranności w zakresie nadzoru. Sąd oddalił pozew, przyjmując, że przepisy federalne o nadzorze bankowym służą ochronie deponentów przed ryzykiem utraty zdeponowanych przez nich środków w przypadku niewypłacalności banku, nie zaś ochronie akcjonariuszy i kantonów gwarantujących zobowiązania ich banku przed ryzykiem restrukturyzacji. Chociaż technicznie i pośrednio chroniony jest również kanton gwarantujący depozyty, jednak nie jest on objęty celem prawnym ochrony.

Cel przepisów dotyczących nadzoru finansowego został zinterpretowany na korzyść deponentów również przez Sąd Najwyższy Austrii w wyroku z dnia 25 marca 2003 roku. Sąd stwierdził, że deponenci są objęci celem ochronnym przepisów o nadzorze bankowym. ${ }^{35}$ Po kryzysie finansowym z 2007 roku wprowadzono jednak zasadę, że państwo jest odpowiedzialne za szkody wyrządzone bezpośrednio podmiotowi nadzorowanemu przez organy i pracowników Finanzmarktaufsicht (FMA) przy wykonywaniu prawa federalnego. ${ }^{36} \mathrm{~W}$ doktrynie wyrażane sa wątpliwości co do konstytucyjności tego rozwiązania oraz jego zgodności z prawem UE. ${ }^{37}$ Pozytywnym przykładem pociagnięcia państwa do odpowiedzialności odszkodowawczej w ostatnich latach jest wyrok austriackiego Sądu Najwyższego z 2012 roku ${ }^{38}$, w którym uznano, że Skarb Państwa odpowiada wobec inwestorów za skutki zaniedbań ze strony organu nadzorującego rynek kapitałowy (BundesWertpapieraufsichtsbehörde). Uznano, że organ ten nie sprawował odpowiedniej kontroli nad prywatnym podmiotem świadczạcym usługi finansowe w sposób oszukańczy.

W tym kontekście należy przypomnieć, że w wyroku Trybunału Sprawiedliwości z dnia 12 października 2004 roku (Peter Paul) ${ }^{39}$ orzeczono, że jeżeli prawo krajowe (tu: niemieckie) ustanawia system gwarantowania depozytów, to dyrektywa 94/19 nie sprzeciwia się przepisowi krajowemu, który wyłacza możliwość ubiegania się przez jednostki o naprawienie szkody wynikłej z zaniedbania w nadzorze ze strony krajowego organu nadzoru nad instytucjami kredytowymi (tj. za brak

33. NJW 2005, 742 .

34. Wyrok z dnia 11 kwietnia 2012 r., A7111/2010, zob. P. Loser, Switzerland, [w:] European Tort Law 2013, [ed.] E. Karner, B.C. Steininger, Springer, Berlin-New York 2014, s. 686.

35. Wyrok OGH z dnia 25 marca 2003 r., 1 Ob 188/02g, [2003] ecolex, 416, zob. B.C. Steininger, Austria, [w:] European Tort Law 2003, [ed.] H. Koziol, B.C. Steininger, Springer, Wien-New York 2004, s. 34.

36. Finanzmarktaufsichtsbehördengesetz (FMABG), BGBII 2001/97 z późn. zm.

37. Zob. B.C. Steininger, Austria, [w:] European Tort Law 2008, [ed.] H. Koziol, B.C. Steininger, Springer, Berlin-New York 2009, s. 114-115.

38. Wyrok OGH z dnia 22 czerwca 2012, 1 Ob 186/11.

39. Wyrok w sprawie C-222/02 Peter Paul, Cornelia Sonnen-Lütte and Christel Mörkens v. Bundesrepublik Deutschland, ECLI:EU:C:2004:606. 1). 
wypłaty depozytu) lub pociaggnięcia państwa do odpowiedzialności za naruszenie prawa Unii ze względu na to, że zadania te są wykonywane w interesie publicznym. ${ }^{40}$ Należy jednak dodać, że nieprawidłowe wdrożenie i stosowanie przepisów dyrektywy, np. tych dotyczących warunków ustalenia niedostępności depozytów (art. 1 pkt 3 ppkt (i) dyrektywy 94/19), a w konsekwencji nieprawidłowe funkcjonowanie mechanizmu kompensacyjnego, może w konkretnych okolicznościach stanowić dostatecznie poważne naruszenie prawa Unii, mogące skutkować odpowiedzialnościa danego państwa członkowskiego ${ }^{41}$ Co więcej, w świetle wyroku Trybunału z dnia 4 października 2018 roku (Kantarev przeciwko Balgarska Narodna Banka) przepisy krajowe nie moga uzależniać prawa jednostek do otrzymania odszkodowania z tytułu naruszenia prawa UE od dodatkowej przesłanki, dotyczącej umyślnego charakteru szkody wyrządzonej przez organ krajowy, a przesłanka „zawinionego działania” banku centralnego nie może być interpretowana w sposób wykraczający poza przesłankę „wystarczająco istotnego naruszenia prawa Unii”. ${ }^{42}$

\section{Stanowisko prawa polskiego}

W Polsce organem nadzoru finansowego jest Komisja Nadzoru Finansowego, której status reguluje obecnie ustawa o nadzorze nad rynkiem finansowym. ${ }^{43} \mathrm{~W}$ wyniku ewolucji systemu nadzoru w Polsce przyjęto model nadzoru skonsolidowanego nad wszystkimi sektorami rynku finansowego. Zgodnie z art. 1 ust. 2 ww. ustawy nadzór nad rynkiem finansowym obejmuje nadzór bankowy, nadzór emerytalny, nadzór ubezpieczeniowy, nadzór nad rynkiem kapitałowym, nadzór nad instytucjami pieniądza elektronicznego, nadzór uzupełniający, nadzór nad spółdzielczymi kasami oszczędnościowo-kredytowymi i Krajową Spółdzielczą Kasą Oszczędnościowo-Kredytową, a także nadzór nad pośrednikami kredytu hipotecznego oraz ich agentami. Środki nadzorcze podejmowane mogą być zgodnie z przepisami szczegółowymi obejmującymi dany sektor rynku finansowego.

Niewątpliwie Komisja Nadzoru Finansowego wykonuje władzę publiczną w rozumieniu przepisów art. 417-421 k.c., które ustanawiają autonomiczny reżim odpowiedzialności odszkodowawczej za bezprawne wykonywanie władzy publicznej ${ }^{44}$, stanowiący rozwinięcie formuły konstytucyjnej wyrażonej w art. 77 ust. 1 Konstytucji RP. Zgodnie z art. 417 k.c. zdarzeniem sprawczym prowadzącym do odpowiedzialności ex delicto jest działanie lub zaniechanie przy wykonywaniu władzy

40. Zob. Dyrektywa 94/19/WE Parlamentu Europejskiego i Rady z dnia 30 maja 1994 r. w sprawie systemów gwarancji depozytów, Dz. Urz. L 135 , 31/05/1994 P. 0005 - 0014.

41. Opinia rzecznik generalnej J. Kokott z dnia $?$ czerwca 2018 r. w sprawie C-571/16, Nikolay Kantarev przeciwko Balgarska Narodna Banka, ECLI:EU:C:2018:412.

42. Wyrok Trybunału (piąta izba) z dnia 4 października 2018 r. w sprawie C-571/16 Nikolay Kantarev przeciwko Balgarska Narodna Banka, ECLI:EU:C:2018:807. Trybunał orzekł m.in., że Artykuł 1 pkt 3 ppkt (i) dyrektywy 94/19 w brzmieniu nadanym mu przez dyrektywę 2009/14 jest bezpośrednio skuteczny i stanowi normę prawną mającą na celu przyznanie uprawnień jednostkom, umożliwiającą deponentom wniesienie skargi o naprawienie szkody spowodowanej zwłoką w zwrocie depozytów.

43. Do pewnego stopnia kontrolę nad rynkiem sprawują również inne podmioty, m.in. Prezes Urzędu Ochrony Konkurencji i Konsumentów oraz NBP. Bankowy Fundusz Gwarancyjny, będący państwową osobą prawną, jest odpowiedzialny za działania restrukturyzacyjne wobec podmiotów rynku finansowego, które są ściśle powiązane z działaniami nadzorczymi. Przedstawienie regulacji szczegółowych jest w tym miejscu pominięte.

44. Zob. ustawa z dnia 17 czerwca 2004 r. o zmianie ustawy - Kodeks cywilny oraz niektórych innych ustaw Dz. U. nr 162, poz. 1692. 
publicznej, które można przypisać Skarbowi Państwa, jednostce samorządu terytorialnego lub innej osobie prawnej wykonującej władzę publiczną z mocy prawa. Należy zauważyć, że od dnia 1 stycznia 2019 roku, zgodnie z art. 3 ust. 1 ww. ustawy państwową osobą prawna jest Urząd Komisji Nadzoru Finansowego, nie zaś sama Komisja, której nadano status organu tej szczególnej państwowej osoby prawnej. ${ }^{45}$ Legitymację bierną w procesie posiadać będzie zatem nie Skarb Państwa, lecz Urząd KNF, a ewentualna egzekucja roszczeń będzie kierowana do majątku Urzędu KNF.

Już przed dniem 1 września 2004 roku orzecznictwo przyjęło odpowiedzialność deliktową organu nadzoru bankowego wobec klientów podmiotów nadzorowanych. ${ }^{46} \mathrm{Na}$ tle prawa bankowego z 1989 roku organy NBP posiadały daleko idące uprawnienia wobec niewypłacalnych banków. Sąd Najwyższy orzekł, że NBP jako państwowa osoba prawna ponosi odpowiedzialność za szkody związane ze sprawowaniem nadzoru bankowego, polegające na utracie zgromadzonych przez deponentów oszczędności, na podstawie art. 420 w zw. art. 417 k.c. (w brzmieniu sprzed 1 września 2004 roku), przyjmując winę anonimową funkcjonariuszy Generalnego Inspektoratu Nadzoru Bankowego. ${ }^{4 ?}$

KNF wykonuje zadania wskazane w art. 4 ustawy o nadzorze finansowym oraz innych ustawach sektorowych za pomocą różnych środków o charakterze władczym. Wachlarz dopuszczonych przez prawo ingerencji KNF w sferę prawna podmiotów nadzorowanych jest bardzo szeroki. Działania te przybierają różne formy: od rozstrzygnięć indywidualnych, rekomendacji skierowanych do ogółu podmiotów na danym rynku, przez zbieranie określonych informacji i danych, przekazywania ich organom władzy publicznej, po czynności faktyczne, takie jak dokonywanie wpisu na liście ostrzeżeń publicznych. KNF została przede wszystkim wyposażona w kompetencje do wydawania decyzji administracyjnych i postanowień na podstawie licznych przepisów prawa materialnego, które upoważniają Komisję do rozstrzygania o prawach lub obowiązkach stron postępowań administracyjnych (w przypadku decyzji administracyjnych), albo na podstawie przepisów prawa procesowego, gdy rozstrzygane jest zagadnienie procesowe (w przypadku postanowień i niektórych decyzji administracyjnych). Jest to podstawowy przykład działania władczego, które może stać się źródłem szkody. ${ }^{48}$

W świetle k.c. dochodzenie naprawienia szkody wynikłej z wydania niezgodnej z prawem decyzji administracyjnej ma charakter dwuetapowy. Właściwe postępowanie odszkodowawcze musi być poprzedzone innym postępowaniem, mającym na celu weryfikację zgodności z prawem decyzji (art. $417^{1}$ §2 k.c.). ${ }^{49} \mathrm{~W}$ pozostałych przypadkach (postanowień, innych uchwał KNF niemajacych

45. Ta gruntowana zmiana ustrojowa została wprowadzona ustawą z dnia 9 listopada 2018 r o zmianie niektórych ustaw w związku ze wzmocnieniem nadzoru nad rynkiem finansowym oraz ochrony inwestorów na tym rynku, Dz.U. 2018, poz. 2243 (zob. art. 5).

46. W uchwale składu 7 sędziów SN z dnia 30 kwietnia 1999 r. III CZP 61/98 (OSNC 1999, nr 12, poz. 201) sąd stwierdził, że „[...] w wypadku zaś uchybień ze strony organu nadzoru bankowego - którym w czasie obowiązywania Prawa bankowego z 1989 r. był Narodowy Bank Polski - nie można wykluczyć jego odpowiedzialności odszkodowawczej".

47. Zob. wyrok SN z dnia 28 października 2003 r., I CK 225/02, niepubl.; wyrok SA w Warszawie z dnia 15 marca 2002 r., ACa 1154/01, Wokanda 2003, Nr 7 -8, s. 82.

48. Zob. B. Wojno, Komentarz do art. 11 ustawy o nadzorze nad rynkiem finansowym, [w:] Prawo rynku kapitałowego. Komentarz, [red.] M. Wierzbowski, L. Sobolewski, P. Wajda, CH Beck, Warszawa 2018, Legalis.

49. Dominuje pogląd, że odpowiedzialność Skarbu Państwa za wydanie niezgodnej z prawem decyzji nie jest uzależniona od rażącego naruszenia prawa; przez niezgodność z prawem ostatecznej decyzji, o której mowa w art. $417^{1} \S 2$ k.c. w zw. z art. 77 ust. Konstytucji RP, należy więc rozumieć sprzeczność jej z przepisami, zgodnie z konstytucyjnym ujęciem jego źródeł. Zob. wyrok SN z dnia 19 kwietnia 2012 r., IV CSK 406/11, OSNC-ZD 2012, nr 3, poz. 68, wyrok SN z dnia 16 stycznia 2015 r., III CSK 96/14, OSNC-ZD 2016/1, poz. 20. 
charakteru decyzji] zastosowanie ma zasada ogólna wyrażona w art. 417 § 1 k.c., a więc warunek prejudykatu odpada. Na gruncie art. 417 § 1 k.c. niezgodność z prawem działania lub zaniechania przy wykonywaniu władzy publicznej ustala sąd odszkodowawczy. Dla przyjęcia bezprawia w rozumieniu prawa cywilnego występuje konieczność ustalenia takiego działania sprzecznego z porządkiem prawnym, które łączy się z naruszeniem praw podmiotowych. ${ }^{50}$

Pewne wạtpliwości pojawiaja się w związku z tym, że KNF może podejmować także inne uchwały, w tym kontrowersyjne akty „prawotwórcze”, skierowane do ogółu podmiotów na danym rynku. Zasadniczą kategorią uchwał niemających waloru decyzji (ani postanowień) są uchwały w przedmiocie wydawania rekomendacji adresowanych do podmiotów rynku finansowego, ${ }^{51}$ a także Zasady Ładu Korporacyjnego (stanowiące z pozoru tzw. soft law, lecz z uwagi na uprawnienia Komisji ich nieprzestrzeganie wiąże się z ryzykiem dotkliwych sankcji o charakterze faktycz$n^{n} \mathrm{~m}^{52}$ ]. Kontrowersyjny jest też charakter wpisu na listę ostrzeżeń publicznych KNF. ${ }^{53} \mathrm{Od}$ dnia 1 stycznia 2019 roku większość aktów prawnych KNF jest publikowana w Dzienniku Urzędowym KNF wydawanym przez Przewodniczącego KNF. ${ }^{54}$ Należy w tym miejscu przypomnieć, że prerogatywy władcze zasadzają się na nadanej wyraźnie przez przepisy prawa możliwości wywierania bezpośredniego skutku w sferze praw, wolności lub interesów innych osób, które bez tego upoważnienia normatywnego byłoby nielegalne..$^{55}$ Ingerencja w sferę prawna jednostki dotyczy zarówno adresatów działań, jak i osób trzecich. Środki władczego działania to nie tylko jednostronne akty

50. Zob. B. Lewaszkiewicz-Petrykowska, Wina jako podstawa odpowiedzialności z tytułu czynów niedozwolonych, „Studia Prawno-Ekonomiczne” 1969, nr 2, s. 91.

51. Zob. art. 137 ust. 1 pkt 5 prawa bankowego oraz art. 365 ustawy o działalności ubezpieczeniowej i reasekuracyjnej. Odnośnie do charakteru prawnego zob. P. Wajda, Rekomendacje Komisji Nadzoru Finansowego dla zakładów ubezpieczeń i zakładów reasekuracji, „Wiadomości Ubezpieczeniowe” 2016, nr 3, passim, E. Kowalewski, M.P. Ziemiak, Wytyczne KNF - aspekty prawno-konstytucyjne oraz wpływ na konkurencyjność w branży usług ubezpieczeniowych, [w:] Konkurencja i konkurencyjność na rynku ubezpieczeniowym, [red.] M. Serwach, Fundacja Instytut Zarządzania Ryzykiem Społecznym Warszawa 2015, s. 85 i nast.

52. Zob. trafne uwagi krytyczne: M. Romanowski, A.-M. Weber-Elżanowska, Kilka refleksji na temat kompetencji Komisji Nadzoru Finansowego do wydania Zasad ładu korporacyjnego dla instytucji nadzorowanych, „Wiadomości Ubezpieczeniowe" 2016, nr 3, passim.

53. Zob. E. Kowalewski, M. Ziemiak, Przesłanki wpisu na listę ostrzeżeń publicznych KNFw kontekście działalności ubezpieczeniowej, „Studia luridica Toruniensia” 2017, t. XXI s. 190-191, DOI: http://dx.doi.org/10.12775/ SIT.2017.033 [dostęp: 15.05.2019]. NSA w wyroku z dnia 30 sierpnia 2011 r. (II GSK 1561/11) orzekł, że wpis podmiotu na listę ostrzeżeń publicznych prowadzona przez KNF nie ma charakteru aktu czy czynności, o których mowa wart. $3 \S 2$ pkt 4 prawa o postępowaniu przed sądami administracyjnymi. W dyspozycji tego przepisu ustawy procesowej nie mieści się czynność KNF polegająca na wpisaniu podmiotu na listę ostrzeżeń publicznych, ponieważ to działanie Komisji jest jedynie czynnością faktyczną, która nie wywołuje bezpośrednich ani pośrednich skutków prawnych.

54. Zob. art. 12 ust. 1a-1c. ustawy z dnia 20 lipca 2000 r. o ogłaszaniu aktów normatywnych i niektórych innych aktów prawnych (Dz.U. 2017, poz. 1523). W Dzienniku Urzędowym Komisji Nadzoru Finansowego ogłasza się: 1) uchwały i decyzje Komisji Nadzoru Finansowego, 2) obwieszczenia, ogłoszenia, komunikaty oraz inne akty lub dokumenty, 3) rejestry (listy) - jeżeli przepisy odrębne tak stanowią. W przypadku gdy z przepisów odrębnych nie wynika obowiązek ogłoszenia uchwały KNF w Dzienniku Urzędowym KNF, Komisja może zdecydować o ogłoszeniu podjętej uchwały w tymże Dzienniku. Ponadto Przewodniczący KNF może skierować do ogłoszenia również inne niż określone wyżej obwieszczenia, ogłoszenia lub komunikaty, o ile są związane z zadaniami organów Urzędu KNF.

55. Zob. D. Oliver, Common values and the Public-Private Divide, Butterworths, London-Edinburgh-Dublin 1999, s. 33. 
prawne (generalne i indywidualne), ale też te czynności faktyczne, którym adresat musi się podporządkować. ${ }^{56}$ Podsumowując, kwalifikacja działania KNF jako władczego jest kluczowa, a jednocześnie wystarczająca do oparcia roszczenia na art. 417 § 1 k.c., co oznacza brak konieczności uzyskania uprzedniego stwierdzenia niezgodności danego aktu (uchwały) z prawem. Niezgodność tę ustali sam sąd odszkodowawczy.

Należy podkreślić, że w kontekście sprawowania nadzoru finansowego problem ustalenia bezprawności dotyczyć będzie przede wszystkim oceny zaniechania podjęcia środka nadzorczego. Z zasady legalizmu wynika nakaz posiadania przez organy władzy publicznej podstawy ustawowej do podejmowania działań prawnych w sposób w niej określony. Zaniechanie podjęcia czynności władczych w formie aktów administracyjnych lub normatywnych można więc wywodzić tylko z naruszenia przepisów prawa. Inaczej można oceniać zaniechanie czynności faktycznych (materialnych), np. działań prewencyjnych. Tradycyjne stanowisko judykatury zakładało, że odpowiedzialność odszkodowawcza Skarbu Państwa za zaniechanie istnieje tylko w sytuacji niepodjęcia działania, do którego był on zobowiązany na podstawie przepisu prawa, przewidującego na czym konkretnie powinno polegać zachowanie Skarbu Państwa, aby do szkody nie doszło. ${ }^{57}$ Obecnie trafne jest zapatrywanie, oparte również na wcześniejszej judykaturze, że zaniechanie przy wykonywaniu władzy publicznej może polegać na naruszeniu obowiązku działania wynikającego z ogólnych przepisów prawa, a także z zasad współżycia społecznego. ${ }^{58}$

Na koniec należy dodać, że realizacja niektórych zadań nadzorczych KNF, m.in. w zakresie wspierania rozwoju innowacyjności rynku finansowego lub mających na celu rozwój rynku finansowego i jego konkurencyjności, może odbywać się w formach niewładczych (np. komunikacja z zainteresowanymi podmiotami, przedstawianie stanowisk w procesach legislacyjnych ${ }^{59}$ ). Czynności powyższe nie będa prowadzić do odpowiedzialności zaostrzonej z art. 417 k.c.

Podsumowując, w świetle surowego reżimu odpowiedzialności kodeksowej należy uznać, że obowiązujące prawo polskie szeroko zakreśla ramy odpowiedzialności za wykonywanie nadzoru finansowego, co podyktowane jest przede wszystkim gwarancyjnym charakterem art. 77 ust. 1 Konstytucji. Nie wnosi przy tym nowej treści normatywnej przepis art. 133 ust. 4 prawa bankowego, który stanowi, że „Komisja Nadzoru Finansowego oraz osoby wykonujące czynności nadzoru bankowego nie ponoszą odpowiedzialności za szkodę wynikłą ze zgodnego z przepisami ustaw działania lub zaniechania, które pozostaje w związku ze sprawowanym przez Komisję Nadzoru Finansowego nadzorem nad działalnością banków, oddziałów i przedstawicielstw banków zagranicznych oraz oddziałów instytucji kredytowych." Nie ma w naszym porządku prawnym jakiejś ogólnej zasady ponoszenia odpowiedzialności odszkodowawczej za działania zgodne z prawem. W tym celu muszą być ustanowione szczególne podstawy prawne. W świetle Kodeksu cywilnego, jeżeli zachowanie podmiotu wykonującego władzę publiczną było legalne, to podlega kompensacji

56. Od aktów prawnych sensu stricto różni je brak domniemania ważności. Zob. M. Jaśkowska, Zwiqzanie administracji publicznej prawem, Księga Pamiqtkowa prof. Eugeniusza Ochendowskiego, TNOiK, Toruń 1999, s. 140.

57. Zob. m.in. wyrok SN z dnia 25 marca 2011 r., IV CSK 407/10, niepubl.

58. Zob. M. Nesterowicz, [w:] Kodeks cywilny z komentarzem. Tom 1, [red.] J. Winiarz, Wydawnictwo Prawnicze, Warszawa 1988, s. 395.

59. Zob. B. Wojno, Komentarz do art. 4 ustawy o nadzorze nad rynkiem finansowym, [w:] Prawo rynku kapitałowego. Komentarz, [red.] M. Wierzbowski, L. Sobolewski, P. Wajda, CH Beck, Warszawa 2018, Legalis. 
jedynie szkoda na osobie (art. $417^{2}$ k.c.). Z wykonywaniem nadzoru nad rynkiem finansowym wiążą się zaś zazwyczaj tylko szkody na mieniu.

\section{Podsumowanie}

Teoretyczną podwaliną konstrukcji odpowiedzialności władz publicznych w systemach demokratycznych jest idea praworządności. Odpowiedzialność władzy publicznej jest elementem zasady państwa prawnego, w szczególności gdy chodzi o ochronę konstytucyjnie zagwarantowanych praw obywatelskich i ochronę przed inną ingerencją w sferę prawną jednostki. Zasada państwa prawa prowadzi m.in. do ustalenia równych zasad odpowiedzialności podmiotów prywatnych i publicznych, gdy chodzi o ogólne obowiązki staranności istniejące wobec innych. Praworządność wymaga, aby odpowiedzialność państwa była realizowana w sądach powszechnych, służyła ochronie obywateli, których prawa moga być naruszone wskutek aktów władczych organów władz publicznych. Oczywiście zakres odpowiedzialności władz publicznych jest różny, ponieważ wewnętrzne rozwiązania prawne są ściśle uzależnione od wartości konstytucyjnych, polityki społecznej i prawnej, a także innych czynników gospodarczych, moralnych i kulturowych.

Przedstawiony wyżej przegląd rozwiązań zagranicznych pokazuje, że szczególna ochrona prawna udzielana (głównie przez ustawodawców) organom nadzoru finansowego jest umotywowana obawą, że zagrożenie odpowiedzialnością może mieć negatywny wpływ na ich skuteczne funkcjonowanie. W związku z tym twierdzi się nawet, że wyłączenie odpowiedzialności odnosi w praktyce taki sam skutek, jak ograniczenie odpowiedzialności do rażącego niedbalstwa lub umyślności. ${ }^{60}$ Takie podejście prowadzi niewątpliwie do nadmiernej ochrony władzy publicznej kosztem poszkodowanych jednostek. Zarazem konstytucyjny charakter zasady odpowiedzialności władz publicznych w wielu krajach jest uważany za istotny argument w kontrolowaniu korzystania z uprawnień władz publicznych i rozszerzaniu ochrony interesów obywateli.

Sądy europejskie ostrożnie podchodzą do prób rozszerzenia odpowiedzialności deliktowej, gdy roszczenie dotyczy naprawienia czystej szkody ekonomicznej wynikającej pośrednio z działań nadzorczych państwa. Mimo wszystko, gdy problem kompensacji szkód pojawia się w kontekście błędnych informacji i wprowadzenia w błąd inwestorów lub konsumentów, przeważa wola ochrony słabszych uczestników rynku [ze względu na asymetrię informacyjna] . ${ }^{61}$ Argumenty przemawiające za odpowiedzialnością władz publicznych odnoszą się również do promowania „świadomości odpowiedzialności" oraz wartości w postaci przejrzystości i efektywności rynków finansowych. Należy dodać, że w zakresie nadzoru bankowego ograniczenia odpowiedzialności dotyczą w zasadzie tej części strat, które nie zostały lub nie mogły zostać pokryte przez fundusze gwarancji depozytów lub systemy gwarancji depozytów.

60. Co oszczędza koszty społeczne. Zob. D. Nolan, op. cit., s. 221-222.

61. Zob. C. Amato, Ch. Perfumi, Financial investors as consumers and their protection: Recent Italian legislation from a European perspective, „Opinio Juris” 2010, nr 2, Paper no 3, 1-23, http://www.opiniojurisincomparatione.org/opinio/article/view/41 [dostęp: 15.05.2019]. 


\section{Wykaz źródeł}

Amato C., Perfumi Ch., Financial investors as consumers and their protection: Recent Italian legislation from a European perspective, „Opinio Juris” 2010, nr 2, Paper no 3, 1-23.

Bagińska E., Liability in Tort of Financial Supervisory Authorities - a comparative analysis, „Studia luridica Toruniensia" 2018 [w druku].

Bagińska E., Odpowiedzialność odszkodowawcza za wykonywanie władzy publicznej, CH Beck, Warszawa 2006.

Baretić M., Croatia, [w:] European Tort Law 2015, Karner E., Steininger B.C. [ed.], Springer, BerlinNew York 2016.

Bargelli E., Italy, [w:] European Tort Law 2011, Oliphant K., Steininger B.C. [ed.], Springer, BerlinNew York 2012.

Bączyk M., Zarys prawa bankowego. Część I. Prawo systemu bankowego, TNOiK, Toruń 2000.

Dijkstra R.J., Is limiting financial supervisory liability a way to prevent defensive conduct? The outcome of a European survey, „European Journal of Law and Economics” 2017, nr 43.

Dijkstra R.J., Liability of Financial Supervisory Authorities in the European Union, „Journal of European Tort Law" 2012, nr 3.

Emaus J.M., Keirse A.L.M., The Netherlands, [w:] European Tort Law 2012, Oliphant K., Steininger B.C. [ed.], Springer, Berlin-New York 2013.

Emaus J.M., Keirse A.L.M., The Netherlands, [w:] European Tort Law 2014, Karner E., Steininger B.C. [ed.], Springer, Berlin-New York 2015.

Faure M.G., Hartlief T., The Netherlands, [w:] European Tort Law 2007, Karner E., Steininger B.C. [ed.], Springer, Wien-New York 2008.

Jaśkowska M., Zwiqzanie administracji publicznej prawem, Księga Pamiqtkowa prof. Eugeniusza Ochendowskiego, TNOiK, Toruń 1999.

Karner E., Tort Law and the Financial Crisis: Basic Questions, „Journal of European Tort Law” 2013, nr 4. Komentarz do ustawy o nadzorze nad rynkiem finansowym, [w:] Prawo rynku kapitałowego. Komentarz, Wierzbowski M., Sobolewski L., Wajda P. [red.], CH Beck, Warszawa 2018, Legalis. Kowalewski E., Ziemiak M., Przesłanki wpisu na listę ostrzeżeń publicznych KNF w kontekście działalności ubezpieczeniowej, „Studia Iuridica Toruniensia” 2017, t. XXI.

Kowalewski E., Ziemiak M.P., Wytyczne KNF-aspekty prawno-konstytucyjne oraz wpływ na konkurencyjność w branży usług ubezpieczeniowych, [w:] Konkurencja i konkurencyjność na rynku ubezpieczeniowym, Serwach M. [red.], Fundacja Instytut Zarządzania Ryzykiem Społecznym, Warszawa 2015.

Lewaszkiewicz-Petrykowska B., Wina jako podstawa odpowiedzialności z tytułu czynów niedozwolonych, „Studia Prawno-Ekonomiczne” 1969, nr 2.

Loser P., Switzerland, [w:] European Tort Law 2013, Karner E., Steininger B.C. [ed.], Springer, Berlin-New York 2014.

Martin-Casals M., Ribot J., The liability of public authorities in Spain, [w:] The Liability of Public Authorities in Comparative Perspective, Oliphant K. [ed.], Intersentia, Cambridge-AntwerpPortland 2016.

Michór A., Komisja nadzoru finansowego jako gwarant stabilności systemu finansowego w Polsce, „Prawo Mediów Elektronicznych” 2010, nr 1. 
Navarretta E., Bargelli E., Italy, [w:] European Tort Law 2001, Koziol H., Steininger B.C. [ed.], Springer, Wien-New York 2002.

Nesterowicz M., [w:] Kodeks cywilny z komentarzem. Tom 1, [red.] Winiarz J., Wydawnictwo Prawnicze, Warszawa 1988.

Nolan D., The Liability of Financial Supervisory Authorities, „Journal of European Tort Law” 2013, nr 4. Oliphant K., The liability of public authorities in comparative perspective, [w:] The Liability of Public Authorities in Comparative Perspective, Oliphant K. [ed.], Intersentia, Cambridge-AntwerpPortland 2016.

Oliver D., Common values and the Public-Private Divide, Butterworths, London-Edinburgh-Dublin 1999.

Papier H.J., [w:] Münchener Kommentar, Schuldrecht, Besonderer Teil, CH Beck, München 1997.

Romanowski M., Weber Elżanowska A.-M., Kilka refleksji na temat kompetencji Komisji Nadzoru

Finansowego do wydania Zasad ładu korporacyjnego dla instytucji nadzorowanych, „Wiadomości Ubezpieczeniowe" 2016, nr 3.

Selelionyte-Drukteiniene S., Saltinyte L., Lithuania, [w:] Karner E., Steininger B.C. [ed.], European Tort Law 2015, Springer, Wien-New York 2016.

Steininger B.C., Austria, [w:] European Tort Law 2003, Koziol H., Steininger B.C. [ed.], Springer, Wien-New York 2004.

Steininger B.C., Austria, [w:] European Tort Law 2008, Koziol H., Steininger B.C. [ed.], Springer, Wien-New York 2009.

Wajda P., Rekomendacje Komisji Nadzoru Finansowego dla zakładów ubezpieczeń i zakładów reasekuracji, „Wiadomości Ubezpieczeniowe” 2016, nr 3.

\section{An overview of the civil liability framework of national financial supervisors (in the light of foreign experience)}

The article reviews legislation and case law in European states regarding claims of individuals and shareholders who seek monetary compensation against public authorities for failure to supervise financial market and its institutions. The author presents the evolution of the standard of liability in Poland and selected other countries. The doctrine of the protective purpose of legal rules and its impact on the extent of liability is also discussed. In this comparative context the liability of the Polish Supervisory authority is then outlined. Finally, policy arguments for and against tortious liability of financial supervisory authorities are summarised.

Key words: tortious liability of financial supervisory authorities, failure to supervise financial market and its institutions, monetary compensation.

PROF. DR HAB. EWA BAGIŃSKA - Katedra Prawa Cywilnego, Uniwersytet Gdański, członek European Group on Tort Law.

https://orcid.org/0000-0003-2950-8484 